\title{
Effect of Different Sun Drying Surfaces on the Functional Properties and Microbial Loads of Unripe Plantain Flours
}

\author{
Olorode Omobolanle Omowunmi*, Ewuoso Latifat Motunrayo \\ Department of Food Technology, Moshood Abiola Polytechnic, Abeokuta, Nigeria
}

Email address:

olorode.omobolanle@mapoly.edu.ng (Olorode O. O.)

\section{To cite this article:}

Olorode Omobolanle Omowunmi, Ewuoso Latifat Motunrayo. Effect of different Sun drying Surfaces on the Functional Properties and Microbial Loads of Unripe Plantain Flours. Frontiers in Environmental Microbiology. Vol. 3, No. 3, 2017, pp. 50-55.

doi: $10.11648 /$ j.fem.20170303.12

Received: March 25, 2017; Accepted: April 25, 2017; Published: August 11, 2017

\begin{abstract}
In order to test the effect of commonly used traditional sun-drying surfaces on some qualities of the product, four traditional sun drying surfaces; wooden, corrugated iron sheet, rock and cement surfaces were used to sundry unripe plantain. The sundried samples were milled to flours. Functional, pasting properties and microbial loads of the resulting flours were determined using standard methods. Values of the functional properties determined except bulk density (packed) and solubility were higher in the rock followed by samples dried on cement surface compare to others. Functional properties except oil absorption and solubility generally improved with storage. Pasting property shows that, samples dried on the rock followed by samples dried on cement surface had the highest values in terms of peak viscosity, trough and final viscosity. There was no significant difference $(\mathrm{P} \geq 0.05)$ in breakdown and pasting temperature. Results of the microbial loads monitored for a period of two months show that at the initial stage, flours of samples sundried on rock had the highest microbial growth while samples dried on corrugated iron had the lowest. There was no significant difference $(\mathrm{P} \geq 0.05)$ in others. There was increase in microbial loads of samples dried on rock and corrugated iron but decreased in others after one month of storage. After storing for a period of two months, microbial loads of samples dried on the rock and cemented surfaces increased while no growth was recorded for samples from wooden and corrugated iron. The report from this research work revealed that rock and cemented surfaces are recommended for sun drying unripe plantain for better functionality of the flour while wood and corrugated iron surfaces are recommended based on microbial load for better storability.
\end{abstract}

Keywords: Sun Drying Surfaces, Unripe Plantain, Rock Surface, Functional Properties, Microbial Loads

\section{Introduction}

Plantain belongs to the Musacace family and is cultivated in many tropics and subtropical countries of the world. It ranks third after yam and cassava for sustainability in Nigeria [1]. It can either be consumed unripe (roasted, boiled or processed into flour or ripe (eaten fresh or fried) and the nutritional value of unripe plantain makes it stand out as a very important addition to a healthy living diet plan.

Unripe plantain meal is usually consumed by Nigeria diabetics to reduce postprandial glucose level [2, 3]. [4] also stated that, unripe plantain flour is used by the traditional medical practitioners in Nigeria in the dietary management of diabetes mellitus and other disease conditions.

The meal process involved drying and blending into flour which can be reconstituted to form paste or stiff dough that is eaten with soup by the consumers [5-7].

However, unripe plantains are abundant at a particular period when it is in season and are scarce when they are out of season. Due to the fact that plantains are highly perishable after harvest, drying is a common practice for preserving them, in order to make them available throughout the year [8].

Sun, oven and solar drying are the popular drying methods being practice $[9,10]$. The most popular drying method being practice in Nigeria is sun drying due to its simplicity $[11,12]$.

The slices of unripe fruits are normally spread out on bamboo frame works or on bare patches of earth, roofs, stone and crops or on sheets of corrugated iron [13].

Various studies have been done on the processing and utilization of plantain in various forms [14-16]. 
The effect of sun drying surfaces on the functional properties and storability of cowpea (Vigna uguiculata) seed have been investigated $[11,12]$ and the result shows significant effect of the sun drying surfaces examined on the properties of cowpea evaluated.

However, there is little or no well documented report on the effect of sun drying surfaces on the properties of unripe plantain products. Therefore, the main objective of this study was to investigate the effect of different sun drying surfaces on the functional properties and microbial loads of unripe plantain flour.

\section{Material and Method}

\subsection{Source of Material}

The unripe plantain was sourced from Lafenwa market, the polythene was sourced from Panseke market while the sodium benzoate was sourced from the Biochemical Laboratory of Food Technology Department, Moshood Abiola Polytechnic all in Abeokuta, Ogun State, Nigeria.

\subsection{Methodology}

\subsubsection{Preparation of Unripe Plantain}

It consists of peeling the skin with knife and then the pulp was sliced to the thickness of $(5 \mathrm{~mm})$ using vennier caliper into sodium benzoate water in order to prevent browning of the pulp. The water was drained out of the pulp with the use of a sieve and the whole sliced pulp was divided into four portions of constant weight [17].

\subsubsection{Sundrying of Unripe Plantain}

The methods of $[11,12]$ was adopted with little modification for sun drying. The methods include; corrugated iron sheet, cemented pavement, wooden surface and rock. The sliced pulp of the unripe plantain was dried on four different surfaces. The first portion of the sliced pulp was spread on low density polythene which was then placed on the rock. The second portion of the sliced pulp was spread on low density polythene and then spread on cemented surface. The third portion of the pulp was spread on a low density polythene before it was been placed on the corrugated iron sheet while the fourth portion of the pulp was also spread on a low density polythene before it was been placed on the wood surface. All were spread between the hours of $10 \mathrm{am}$ and $4: 30 \mathrm{pm}$ for five (5) days to dry to breakage and crispness.

\subsubsection{Production of Unripe Plantain Flour}

The method of [17] was used for the production of the unripe plantain flour. The dried crispy pulp was grounded using Attrition mill. The plantain flour was allowed to cool, packaged in polythene and labeled accordingly.

\subsubsection{Storage of Unripe Plantain Flour}

The sundried packaged unripe plantain flour was stored at room temperature and was analyzed at the initial stage, stored and then analyzed each month for the period of two (2) months.

\subsection{Analysis of Samples}

\subsubsection{Determination of Functional and Pasting Properties}

The Water absorption capacity was determined according to the method of [18]. The result was expressed as a percentage of water absorbed by the flours on dry weight basis. (Density of water was assumed to be $1 \mathrm{~g} / \mathrm{ml}$ ). The method described by [19] was used to determine the swelling capacity while the solubility was calculated after the determination of swelling capacity as per $100 \mathrm{~g}$ of starch on dry basis. $5 \mathrm{ml}$ of aliquot of the supernatant was dried to a constant weight at $120^{\circ} \mathrm{C}$. The residue obtained after drying represents the amount of starch solubilized in water using the method of [19]. The procedure of [20] was used to determine the bulk density (packed and loosed) of the plantain flour. The Least gelation concentration was determined using the method of [21]. It was taken as the least concentration when the sample from the inverted test tube did not fall or slip. Oil absorption capacity was also determined using the method of [22]. Pasting properties was determined with Rapid viscous analyzer as adopted by [23].

\subsubsection{Determination of Microbial Loads}

The sample was thoroughly mixed in order to have microorganism evenly distributed. $1.0 \mathrm{~g}$ of sample was homogenized in $9.0 \mathrm{ml}$ sterile $0.1 \%$ peptone water for secs. (normal speed). This was serially diluted in sterile peptone water according to [24]. Serial ten fold dilutions of the bacterial suspension over a range were prepared. One dilution contain between 50 and 500 viable bacterial per ml. $9 \mathrm{ml}$ of buffered saline was added to the $1^{\text {st }}$ tube and $1 \mathrm{ml}$ of the dilute buffered saline was added to the $2^{\text {nd }}$ tube till the last $\left(6^{\text {th }}\right)$ tube. $1 \mathrm{ml}$ of the bacterial suspension was also added into the test tube which was also mixed continuously till it gets to the $6^{\text {th }}$ tube, then $1 \mathrm{ml}$ is discarded. This gives a dilution of $1 / 10,1 / 20,1 / 40,1 / 80,1 / 160,1 / 320$. $1 \mathrm{ml}$ each dilution was pipette into sterile Petri-dishes and nutrient agar was poured over it. All media and dilutions used were sterile at the temperature of $121^{\circ} \mathrm{C}$ and pressure of $1.02 \mathrm{kgcm}^{-1}$ by autoclaving. The total plate count was done by plating $1 \mathrm{ml}$ aliquot samples on plate count agar (PCA) and incubating at $30^{\circ} \mathrm{C}$ for $48 \mathrm{~h}$ [24].

\subsection{Statistical Analysis}

Analyses were done in triplicates and the mean value determined in each case. Data obtained were subjected to appropriate statistical analysis (SPSS 16.0) and the means were separated by Duncan Multiple Range Test where significant difference occurs.

\section{Result and Discussion}

\subsection{Result and Discussion on the Functional Properties of the Plantain Flours}

The result of the functional properties of the plantain 
flours is as shown in table (1). Oil Absorption Capacity (OAC) indicates the ability of a flour to retain flavor and improve mouth feel [25]. OAC has been attributed to be due to physical entrapment of oil and the binding of fat to the polar chains of protein. [25] reported that more hydrophobic proteins show superior binding of lipids. Therefore, the lower OAC of the sample dried on the Rock, corrugated iron and wood may be due to the fact that the sample dried on the cemented surface (CS) (with a higher OAC) has more available non-polar side chains in its protein molecules than samples dried on the other surfaces and it's implies that the sample dried on the cemented surface will be able to retain more flavor and probably have a better mouth feel compared to the others.

According to [26], Water Absorption Capacity (WAC) is the ability of a product to associate with water under a condition where water is limiting. However, the higher WAC of the sample dried on the cemented surface compared to the sample dried on rock, corrugated iron and wood shows that it will make the sample dried on the cemented surface to absorb and bind more water.

Result of the least gelation capacity shows that the samples dried on the rock, cemented surface and corrugated iron are lower while the sample dried on the wood has the highest least gelation capacity (table 1 ).

Table 1. Functional Properties of Flours of Unripe Plantain Dried on different Sun drying Surfaces at the Initial Stage.

\begin{tabular}{lllll}
\hline Parameters & A & B & C & D \\
\hline Oil Absorption Capacity\% & $21.00^{\mathrm{b}}$ & $25.00^{\mathrm{a}}$ & $22.00^{\mathrm{b}}$ & $24.00^{\mathrm{a}}$ \\
Water Absorption Capacity\% & $13.00^{\mathrm{b}}$ & $17.00^{\mathrm{a}}$ & $12.00^{\mathrm{b}}$ & $11.00^{\mathrm{b}}$ \\
Least Gelation Capacity\% & $0.60^{\mathrm{b}}$ & $0.60^{\mathrm{b}}$ & $0.60^{\mathrm{b}}$ & $0.80^{\mathrm{a}}$ \\
Bulk Density (Packed) $\mathrm{g} / \mathrm{ml}$ & $0.55^{\mathrm{c}}$ & $0.56^{\mathrm{b}}$ & $0.59^{\mathrm{a}}$ & $0.54^{\mathrm{d}}$ \\
Bulk Density (loose) $\mathrm{g} / \mathrm{ml}$ & $0.46^{\mathrm{a}}$ & $0.45^{\mathrm{ab}}$ & $0.44^{\mathrm{b}}$ & $0.41^{\mathrm{c}}$ \\
Swelling Capacity\% & $195.52^{\mathrm{a}}$ & $187.48^{\mathrm{b}}$ & $150.32^{\mathrm{c}}$ & $151.28^{\mathrm{c}}$ \\
Solubility\% & $3.00^{\mathrm{c}}$ & $3.65^{\mathrm{c}}$ & $5.88^{\mathrm{b}}$ & $7.16^{\mathrm{a}}$ \\
\hline
\end{tabular}

Each value is a mean of triplicate determinations.

Data in same row with the same superscripts are not significantly different $(\mathrm{P} \geq 0.05)$

The bulk density (packed) shows that the sample dried on the corrugated iron was significantly higher than other samples dried on the rock, cemented surface and wood and the bulk density (loose) shows that the sample dried on the rock was significantly higher than the other samples. The bulk density is important in the packaging requirement and material handling of flour [27]. The loose packed density is related to the bulk density, the higher the loose pack density the higher the packed bulk density. A large free space is undesirable in packaging of foods because it constitute a large oxygen reservoir where as a low loose bulk density and lower bulk density result in greater oxygen transmission in the packed food [27]. Therefore it shows that the low bulk density of the unripe plantain dried on the cemented surface, corrugated iron and wood will enhance their packaging.

Swelling capacity refers to the expansion accompanying spontaneous uptake of solvent. According to [25], swelling causes changes in hydrodynamic properties of the food thus impacting characteristics such as body, thickening and increase in viscosity to foods. This implies that among this flour the samples dried on the rock followed by the cemented surface with the highest swelling capacity will produce a think viscous meal compared to others.

Solubility index is the amount of water soluble solids per unit weight of the sample. Solubility is an index of protein functionality such as denaturation and its potential applications. [28] stated that the higher the solubility, functionalities of the protein in a food. The sample dried on the wood has the highest solubility which shows that the protein is higher in functionalities than the others.

After storage the oil absorption capacity of the result shown at table 2 indicate that the sample dried in the cemented surface still has the highest oil absorption capacity which implies that the flour will be able to retain more flavour and probably have a better mouth feel compared to others after storage. The water absorption capacity also shows that sample dried on the cemented surface had the highest WAC even after storage which implies that the flour would be able to absorb and bind more water than others. The lower values recorded for others may have been due to reduction in the active sites capable of imbibing water due to the denaturation of protein.

Table 2. Functional Properties of Flours of Unripe Plantain Dried on different Sun drying Surfaces after Storage.

\begin{tabular}{lllll}
\hline Parameters & A & B & C & D \\
\hline Oil Absorption Capacity\% & $17.00^{\mathrm{ab}}$ & $18.00^{\mathrm{a}}$ & $16.50^{\mathrm{ab}}$ & $16.00^{\mathrm{b}}$ \\
Water Absorption Capacity\% & $19.00^{\mathrm{a}}$ & $20.00^{\mathrm{a}}$ & $19.50^{\mathrm{a}}$ & $19.00^{\mathrm{a}}$ \\
Least Gelation capacity $\%$ & $0.80^{\mathrm{a}}$ & $0.80^{\mathrm{a}}$ & $0.80^{\mathrm{a}}$ & $0.80^{\mathrm{a}}$ \\
Bulk Density (Packed) $\mathrm{g} / \mathrm{ml}$ & $0.63^{\mathrm{c}}$ & $0.66^{\mathrm{a}}$ & $0.64^{\mathrm{b}}$ & $0.64^{\mathrm{b}}$ \\
Bulk Density (loose) $\mathrm{g} / \mathrm{ml}$ & $0.48^{\mathrm{a}}$ & $0.41^{\mathrm{c}}$ & $0.42^{\mathrm{c}}$ & $0.43^{\mathrm{b}}$ \\
Swelling Capacity\% & $179.64^{\mathrm{b}}$ & $213.56^{\mathrm{a}}$ & $173.48^{\mathrm{c}}$ & $134.52^{\mathrm{d}}$ \\
Solubility\% & $1.80^{\mathrm{b}}$ & $1.40^{\mathrm{c}}$ & $1.24^{\mathrm{d}}$ & $3.04^{\mathrm{a}}$ \\
\hline
\end{tabular}

Each value is a mean of triplicate determinations.

Data in same row with same superscripts are not significantly different $(\mathrm{P} \geq 0.05)$

The bulk density (packed) after storage shows that the sample dried on the cemented surface is higher than the other samples dried on the wood, corrugated iron and rock which suggest the suitability of flour with high bulk density for use in food preparations. On contrast, low bulk density would be an advantage in the formulation of complementary foods [29]. Meanwhile, the bulk density (loose) show that the sample dried on the rock is higher than the other samples. Therefore it shows that the low loose bulk density of the samples dried on the cemented surface, corrugated iron and wood will enhance their packaging. The least gelation capacity of the result after storage shows that the samples dried on the four surfaces did not show any significant differences.

After storage the swelling capacity indicate that the sample dried on the cemented surface has the highest swelling capacity, therefore this implies that the flour will produce a thick viscous flour meal compared to others.

Solubility after storage shows that the sample dried on the 
wood has the highest solubility which shows that the protein is higher in functionalities than the others.

The result of the pasting properties of the plantain flours is as shown in table 3. Peak viscosity is often correlated with the final product quality. It is the ability of starch to swell freely before their physical breakdown [30] and measures the ability of the paste to break down during cooking. It also provides an indication of the viscous load likely to be encountered during mixing $[31,32]$. The sample dried on the rock has the highest peak viscosity compared with other samples dried on the cemented surface, corrugated iron and wood.

Table 3. Pasting Properties of Flours of Unripe Plantain Dried on different Sun drying Surfaces.

\begin{tabular}{lllll}
\hline Parameters & A & B & C & D \\
\hline Peak Viscosity RVU & $3289.50^{\mathrm{a}}$ & $2992.00^{\mathrm{b}}$ & $2557.00^{\mathrm{c}}$ & $2785.00^{\mathrm{c}}$ \\
Trough RVU & $3065.50^{\mathrm{a}}$ & $2832.50^{\mathrm{b}}$ & $2395.00^{\mathrm{c}}$ & $2574.00^{\mathrm{c}}$ \\
Breakdown RVU & $224.00^{\mathrm{a}}$ & $159.50^{\mathrm{b}}$ & $162.00^{\mathrm{b}}$ & $210.50^{\mathrm{a}}$ \\
Final Viscosity RVU & $4170.50^{\mathrm{a}}$ & $3824.50^{\mathrm{b}}$ & $3133.50^{\mathrm{d}}$ & $3515.00^{\mathrm{c}}$ \\
Set Back RVU & $1105.80^{\mathrm{a}}$ & $992.00^{\mathrm{b}}$ & $738.50^{\mathrm{c}}$ & $940.50^{\mathrm{b}}$ \\
Peak Time (minutes) & $6.57^{\mathrm{a}}$ & $6.60^{\mathrm{a}}$ & $6.10^{\mathrm{b}}$ & $6.50^{\mathrm{a}}$ \\
Pasting Temperature $\left({ }^{\circ} \mathrm{C}\right)$ & $83.60^{\mathrm{a}}$ & $83.50^{\mathrm{a}}$ & $84.00^{\mathrm{a}}$ & $83.98^{\mathrm{a}}$ \\
\hline
\end{tabular}

RVU= Rapid viscosity units

Each value is a mean of duplicate determinations

Data in same row with same superscripts are not significantly different $(\mathrm{P} \geq 0.05)$

Note: Sample A - Flour from Unripe plantain sundried on the Rock Sample B - Flour from Unripe plantain sundried on Cemented Surface

Sample C - Flour from Unripe plantain sundried on Corrugated Iron Sheet

Sample D - Flour from Unripe plantain sundried on the Wood

All packaged in polythene

Trough is the minimum viscosity value in the constant temperature phase or the RVA profile and it measures the ability of paste to withstand breakdown during cooling [30]. The sample dried on the rock has the highest Trough than the other samples dried on the cemented surface, corrugated iron and wood. Meanwhile, there was no significant difference $(\mathrm{P}>0.05)$ between the four samples dried on different surfaces in terms of breakdown viscosities. The breakdown is regarded as a measure of the degree of disintegration of granules or paste stability $[33,34]$. The lower the value, the more stable is the starch gel. Therefore, the starch gel of the sample dried on the cemented surface with the lowest breakdown value (159.50RVU) will be more stable compared to others.

In the final viscosity of the sample dried on the rock has the highest value than the other samples dried on the corrugated iron, cemented surface and wood.

The setback viscosity indicates the tendency of the dough to undergo retrogradation, a phenomenon that causes the dough to become firmer and increasingly resistant to enzyme attack [35]. The higher the setback value, the lower the retrogradation during cooling and the lower the staling rate of product made from the flour [36]. The sample dried on the rock has the highest setback than the samples dried on the corrugated iron, cemented surface and wood. Samples with low set back value indicate that the flour meal on cooking will not be a cohesive meal.

Pasting temperature is a measure of the minimum temperature required to cook a given food sample [37]. There is no significant difference between the flour samples dried on different surfaces.

Peak time is a measure of the cooking time [30]. The sample dried on the rock has the highest peak time than the sample dried on the corrugated iron, cemented surface and wood. Which indicate that a longer time may be needed for cooking to require consistency.

\subsection{Result of the Microbial Load of Flour Produced from Unripe Plantain Pulp Dried on Different Sun Drying Surfaces}

The result of the microbial load of the microbial load of the plantain flour is as shown in table 4. At the initial month, the microbial load recorded between $3.8 \times 10^{4} \mathrm{cfu} / \mathrm{g}$ and $4.0 \mathrm{x}$ $10^{5} \mathrm{cfu} / \mathrm{g}$. The flour of the unripe plantain pulp sundried on the rock had the highest microbial load while the one sundried on the corrugated iron sheet had the lowest. Meanwhile the microbial load recorded after one month of storage period ranges between $1.75 \times 10^{4} \mathrm{cfu} / \mathrm{g}$ to $9.6 \mathrm{x}$ $10^{5} \mathrm{cfu} / \mathrm{g}$ with the flour of the unripe plantain pulp sundried on the rock having the highest microbial load while the one sundried on the cemented surface had the lowest. Meanwhile microbial load recorded after two months of storage ranges between $0 \mathrm{cfu} / \mathrm{g}$ and $1.28 \times 10^{6} \mathrm{cfu} / \mathrm{g}$. The sample sundried on the rock had the highest microbial load followed by the sample sundried on the cemented surface whereas samples sundried on the corrugated iron sheet and wooden surface had no growth.

Table 4. Total Plate Count of Flours of Unripe Plantain Dried on different Sun drying Surfaces.

\begin{tabular}{llll}
\hline Sample & 0 (month) cfu/g & $\left(1^{\text {st }}\right.$ month $)$ cfu/g & $\left(2^{\text {nd }}\right.$ month $) \mathbf{c f u} / \mathbf{g}$ \\
\hline A & $4.0 \times 10^{5}$ & $9.6 \times 10^{5}$ & $1.3 \times 10^{6}$ \\
B & $1.8 \times 10^{5}$ & $1.8 \times 10^{4}$ & $4.8 \times 10^{5}$ \\
C & $3.8 \times 10^{4}$ & $1.8 \times 10^{5}$ & Nil \\
D & $1.8 \times 10^{5}$ & $1.8 \times 10^{4}$ & Nil \\
\hline
\end{tabular}

Note: Sample A - Unripe plantain sundried on the Rock

Sample B - Unripe plantain sundried on Cemented Surface

Sample C - Unripe plantain sundried on Corrugated Iron Sheet

Sample D - Unripe plantain sundried on the Wood

All packaged in polythene

Preservation of food by sun drying is a common practice in different parts of the world and it is used to extend the shelf life of food. Drying allows food to be preserved by removing the moisture in the food, in order to prevent the growth of microorganisms that causes deterioration [10]. The result of this research shows that unripe plantain sundried on the rock had the highest microbial growth. The factors that can affect the microbial growth include; biological factor e.g. Lizard, flies, goat, handling of plantain and microorganisms in the air. The next to the sample dried on the rock in terms of microbial growth was that of the flour samples dried on the cemented surface. The sample sundried on the wooden surface and corrugated iron sheet had no growth. The values 
$\left(10^{4}-10^{6} \mathrm{cfu} / \mathrm{g}\right)$ obtained from unripe plantain sundried on the four different surfaces were within acceptable limit when compared with the international standard recommended, limit of bacteria contaminant for food $\left(<10^{6} \mathrm{cfu} / \mathrm{g}\right)$ as stated by [38]. However, wooden surface and corrugated iron sheet are the most preferred sun drying surfaces for drying unripe plantain since they show to have the lowest microbial growth even after storage.

\section{Conclusion}

This study revealed that the drying of unripe plantain on different surfaces affected some of the functional properties of the flour even up to storage level. Cemented surface shows to be more effective among the sun drying surfaces in terms of the oil absorption capacity, water absorption capacity, bulk density (packed) and swelling capacity of the unripe plantain flours even after storage. The pasting properties show that the Rock is more effective in terms of the peak viscosity, trough, final viscosity and breakdown of the unripe plantain flour.

Wooden surfaces and corrugated iron sheet seems to be the most effective sun-drying surfaces for unripe plantain based on the microbial qualities of the flours from the dried products.

I hereby recommend cemented surface followed by rock surface for sun drying unripe plantain for better functionality of flour. While corrugated iron sheet and wooden surface for sun drying the unripe plantain due to low level of microbial growth after storage compared with the unripe plantain sundried on the rock which had the highest microbial growth.

Further investigation should therefore be done on other sun drying surfaces, the effect of these surfaces on other food produce and the months of storage could be extended.

\section{References}

[1] Akomolafe, O. M. and Aborisade, A. T (2007). Effects of stimulated storage conditions on the quality of plantain (Musa paradisiacal) fruit. Int. J. Agric. Res 2(12): 1037-1042.

[2] Willett, W., Manson, J and Liu, S (2002). Glycemic index, glycemic load and risk of type 2 diabetes. Am. J. Clin. Nutr. 76 (1) $274 \mathrm{~S}-280 \mathrm{~S}$.

[3] Foster G. D., Wyatt, H. R. and Hill, J. O. (2003). A randomized trial of a low carbohydrate diet for obesity. New England. J. Med., 348 (21) 2082-2090.

[4] Eleazu, C. O, Okafor, P. N and Ikpeama, A. I (2010). Total antioxidant capacity, nutritional composition and inhibitory activity of unripe plantain (Musa paradisiaca) on oxidative stress in alloxan induced diabetic rabbits. Pak J Nutr. 9(11): $1052-1057$.

[5] Akinssoe, N., Hounhouigan, D. J., Bricas, N., Vernier, P., Mago, C. M and Olorunda, A., (2001). Physical, chemical and sensory evaluation of dried yam (Dioscorea rotundata) tubers, flour and amala of flour derived product. Trop. Sci. 41: 151155.

[6] Mestres, C., Dorthe, S., Akissoe, N and Hounhouigan, J. D
(2004). Prediction of sensorial properties (colour and taste) of amala, a paste from yam chips flour of West Africa, through flour biochemical properties. Foods. Hum. Nutri: 93-99.

[7] Emperatriz, P. O., Ronald, M., Elevina, P. and Mily, S. (2008). Production and characterization of unripe plantain (Musa paradisiaca) flours. Intercienca, 33: 290-296.

[8] Habou, D., Asere, A. A. and Alhassan, A. M. (2003). Comparative study of the drying rate of tomatoes and pepper using forced and natural convection solar dryer. Nig. J. Renew. Energy, 14: 36-40.

[9] Matazu, I. K. and Harous, A. A. (2004). The effect of drying methods on the nutrients and non-nutrients composition of the fruit of Hibiscus esculentus (Okra). Nig. J. Renew. Energy, 11: 9-13.

[10] Mukhtar. F. B., (2009). Effect of storage temperature on post harvest deterioration of banana and plantain (Musa sp.). Int. J. Phys. Applied Sci., 3: 28-38.

[11] Arogba, S. S., Ugwu, F. M and Abu, D. D. (1998). The effects of sun-drying surfaces and packaging materials on the storability of cowpea (Vigna unguiculata) seed. Plant foods for human nutrition 53, 113-120.

[12] Ugwu, F. M., Ekwu. F. C. and Abu J. O (1999). Effect of different sundrying surfaces on the functional properties, cooking and insect infestation of cowpea sees. Bioresource Technology. 69: 89-90.

[13] FAO. (Food and Agriculture Organization) (1995). FAO Production year book. Vol. 43. Rome Italy.

[14] Ukhum, M. E and Ukpebor, I. E (1991). Production of instant plantain flour, sensory evaluation and physic-chemical changes during storage. Food Chem., 42: 287-299.

[15] Onyejegbu, L. A. and Olorunda, A. O (1995). Effects of raw materials processing conditions and packaging on the quality of plantain chips. J. Sci. Food. Agric., 68: 279-283.

[16] Ogazi, P. O. (1996). Plantain: production, processing and utilization. Paman and Associates Publishers, Okigwe, Nigeria. Pp. 305.

[17] Ngalani, J. A. (1986). La conservation des fruits tropicaux: cas de la banana plantain. Etude préliminaires. Fruits, 41(2): 8992.

[18] Sathe, S. K. Desphande, S. S. and Salunkhe, D. K. (1982). Functional properties of Lupin seed (Lipinus mutabilis) Protein and protein concentrates Journal of food science 47: 491-497.

[19] Leach, H. W., McCowen L. D. and Scoch, T. J. (1959). Structure of starch granule, swelling and solubility patterns of various starches. Cereal Chemistry 36: 534-544.

[20] Akpapunam, M. A. and Markakis, P. (1987). Physiochemical and nutritional aspects of Cowpea flour. Journal of food Science 46: 972-973.

[21] Coffman, C. W. and Garcia, V. V. (1977). Functional properties of flours prepared from Chinese indigenous legume seed. Food Chemistry 61: 429-433.

[22] Sosulski, F. W., Garatt, M. O and Slinkard, A. E (1976). Functional properties of ten legume flours. Int. J. Food Sci. Technol. 9: 66-69. 
[23] Oyarekua, M. A (2009). Co-fermentation of Cassava/cowpea/carrot to produce Infant complementary food of improved nutritive Quality. Asian Journal of Clinical Nutrition. 1(3): 120-130.

[24] Olutiola, P. O., Famurewa, O. and Sonntage, A. S. (1991). Heidelberger Verlagsanstatt and Onickerei Gmbtl Heidelberg, Germany pp 94-135.

[25] Kinsella, J. E (1976). Function Properties and amino acid content of a protein isolate from mung-bean flour. Journal of Food Technology 12: 473-484.

[26] Singh, U (2001). Functional properties of grain legume flours. J. Food Sci. Technol. 38: 191-199.

[27] Karuna, D., Kulkarni, D. N. and Ingle, U. M. (1996). Fractionation, solubility and functional properties of cowpea (Vigna unguiculata) proteins as affected by $\mathrm{pH}$ and/or salt concentration. J. of Food Chem. 82: 207 - 212.

[28] Omueti, O., Otegbayo B., Jaiyeola O. and Afolabi O (2009). Functional properties of complementary diets developed from Soybean (Glycine max), Groundnut (Arachis hypogea) and Crafish (Macrobrachium spp.). Journal of Environmental, Agricultural and Food Chemistry 8 (8): 563-573.

[29] Akpata, M. I and Akubor, P. I (1999). Chemical composition and selected functional properties of sweet orange (Citrus sinensis) seed flour. Plant Food Hum. Nutr. 54: 353-362.

[30] Adebowale, A. A. Sanni, L. O and Awonorin, S. O (2005). Effect of texture modifiers on the physicochemical and sensory properties of dried fufu. Food. Sci. Technol. Int., 11(5): 373-382.

[31] Maziya-Dixon, B., Dixon, A. G. O and Adebowale, A. A (2004). Targeting different end uses of cassava: Genotypic variations for cyanogenic potentials and pasting properties. A paper presented at ISTRC-AB Symposium. October 31 November 5, 2004, Whitesands Hotel, Mombassa, Kenya.

[32] Maziya-Dixon, B., Sanni, A. A., Adebowale, A. A., Onabanjo, O. O and Dixon, A. G. O (2005). Effect of variety and drying methods on proximate composition and pasting properties of high quality cassava flour from yellow cassava roots. Proceedings of the African Crop Science Society Conference, 5th - 9th December 2005, Enttebe, Uganda.

[33] Dengate, H. N. (1984). Swelling, pasting and gelling of wheat starch. In: Pomeranz Y. (Ed) Adv. Cereal Sci. Technol. AACC, USA, Pp. 49-82.

[34] Newport Scientific (1998). Applications manual for the Rapid Visco Analyzer using thermocline for windows. Newport scientific Pty Ltd., 112 Apollo street, warriewood NSW 2012, Australia, Pp. 2-26.

[35] Ihekoronye, A. I. and Ngoddy, P. O (1985). Browning reaction in integrated Food Science and Technology for the Tropics. Macmillan Education Ltd. London, pp. 224-229.

[36] Onitilo, M. O., Sanni, L. O., Oyewole, O. B and MaziyaDixon, B (2007). Physicochemical and functional properties of sour starches from different cassava varieties. Int. Journal of Food Properties, 10: 607-620.

[37] Sandhu, K. S., Singh, N. and Malhi., N. S. (2007). Some properties of corn grains and their flours l' physicochemical, functional and Chapati-making properties of flours. Food Chem., 101: 938-946.

[38] Anon (1974). Biological specification for food principles and specific applications university of Toronto press. Canada pp 24. 